\title{
ATMOSPHERIC RADIOCARBON FOR THE PERIOD 1950-2010
}

\author{
Quan Hua ${ }^{1} \cdot$ Mike Barbetti $^{2} \cdot$ Andrzej Z Rakowski $^{3}$ \\ ABSTRACT. We present a compilation of tropospheric ${ }^{14} \mathrm{CO}_{2}$ for the period $1950-2010$, based on published radiocarbon \\ data from selected records of atmospheric $\mathrm{CO}_{2}$ sampling and tree-ring series. This compilation is a new version of the com- \\ pilation by Hua and Barbetti (2004) and consists of yearly summer data sets for zonal, hemispheric, and global levels of atmo- \\ spheric ${ }^{14} \mathrm{C}$. In addition, compiled (and extended) monthly data sets for 5 atmospheric zones ( 3 in the Northern Hemisphere \\ and 2 in the Southern Hemisphere) are reported. The annual data sets are for use in regional and global carbon model calcu- \\ lations, while the extended monthly data sets serve as calibration curves for ${ }^{14} \mathrm{C}$ dating of recent, short-lived terrestrial organic \\ materials.
}

\section{INTRODUCTION}

Bomb radiocarbon has been long recognized as an excellent tracer for the study of atmospheric transport, ocean circulation, exchanges between the carbon reservoirs, and the global carbon cycle (Nydal 1968; Oeschger et al. 1975; Broecker et al. 1980; Druffel and Suess 1983; Druffel 1997; Levin and Hesshaimer 2000; Randerson et al. 2002; Hua and Barbetti 2004, 2007; Levin et al. 2010). In addition, the application of bomb ${ }^{14} \mathrm{C}$ in various other research disciplines has grown significantly in the last 2 decades. In particular, atmospheric bomb ${ }^{14} \mathrm{C}$ has been used in forensic studies (Wild et al. 1998; Zoppi et al. 2004; Nakamura et al. 2007; Buchholz and Spalding 2010; Alkass et al. 2011; Ubelaker and Parra 2011; Ehleringer et al. 2012), in biomedical research (Spalding et al. 2005, 2008; Bhardwaj et al. 2006; Lynnerup et al. 2008), and in soil carbon studies (Quideau et al. 2000; Bruun et al. 2005; Koarashi et al. 2009; Trumbore 2009; Rabbi et al. 2013), to build reliable chronologies for recent terrestrial archives and materials (Hua 2009; English et al. 2010; Hodge et al. 2011; Clarke et al. 2012; Hua et al. 2012a), to validate tree-ring ages (Fichtler et al. 2003; Vieira et al. 2005; Bowman et al. 2011; Pearson et al. 2011), to date recent trees having no annual growth rings (Worbes and Junk 1989; Poussart and Schrag 2005; Lovelock et al. 2010), and to determine biogenic and fossil fractions of industrial $\mathrm{CO}_{2}$ emissions (Mohn et al. 2008, 2012; Felner and Rechberger 2009; Palstra and Meijer 2010).

This paper presents a new compilation of tropospheric ${ }^{14} \mathrm{CO}_{2}$ (or tropospheric ${ }^{14} \mathrm{C}$ in short) for the last $60 \mathrm{yr}(1950-2010)$, covering a short interval before the onset of bomb ${ }^{14} \mathrm{C}$ in the mid-1950s, the bomb-peak period during the $1960 \mathrm{~s}$, and the post-bomb era up to very recent time. The compiled data in this paper are a new and extended version of the atmospheric ${ }^{14} \mathrm{C}$ data for $1955-2001$ published by Hua and Barbetti (2004), and are intended to facilitate the fast-growing demand in the applications of atmospheric bomb ${ }^{14} \mathrm{C}$.

\section{ZONAL TROPOSPHERIC ${ }^{14} \mathrm{CO}_{2}$}

Tropospheric $\Delta^{14} \mathrm{C}$ started rising in 1955 due to influences of aboveground nuclear detonations (Figure 1). (We use $\Delta^{14} \mathrm{C}$ to represent the fractionation- and age-corrected deviation from the standard pre-industrial atmospheric ${ }^{14} \mathrm{C}$ concentration [ $\Delta$ of Stuiver and Polach 1977].) $\Delta{ }^{14} \mathrm{C}$ levels increased steadily in most years and reached maximum values in the mid-1960s. In particular, bomb ${ }^{14} \mathrm{C}$ in northern mid- to high latitudes peaked at 1963-1964 with a value at almost double its pre-bomb level (Nydal 1968; Levin et al. 1985). Since then, atmospheric $\Delta{ }^{14} \mathrm{C}$ has decreased due to the

\footnotetext{
${ }^{1}$ Australian Nuclear Science and Technology Organisation (ANSTO), Locked Bag 2001, Kirrawee DC, NSW 2232, Australia. Corresponding author. Email: qhx@ansto.gov.au.

${ }^{2}$ Faculty of Agriculture, Natural Resources and Environment, Naresuan University, Phitsanulok 65000, Thailand.

${ }^{3}$ Leibniz Laboratory for Radiometric Dating and Isotope Research, University of Kiel, Germany.
} 
absence of major atmospheric nuclear explosions, and rapid exchange between the atmosphere, oceans, and biosphere. Combustion of fossil fuel free of ${ }^{14} \mathrm{C}$ has also contributed to the decrease of atmospheric $\Delta^{14} \mathrm{C}$, especially since the late 1980s (Levin et al. 2010) and early 1990s (Graven et al. 2012a). Currently, atmospheric $\Delta^{14} \mathrm{C}$ is slightly higher than its pre-bomb value.

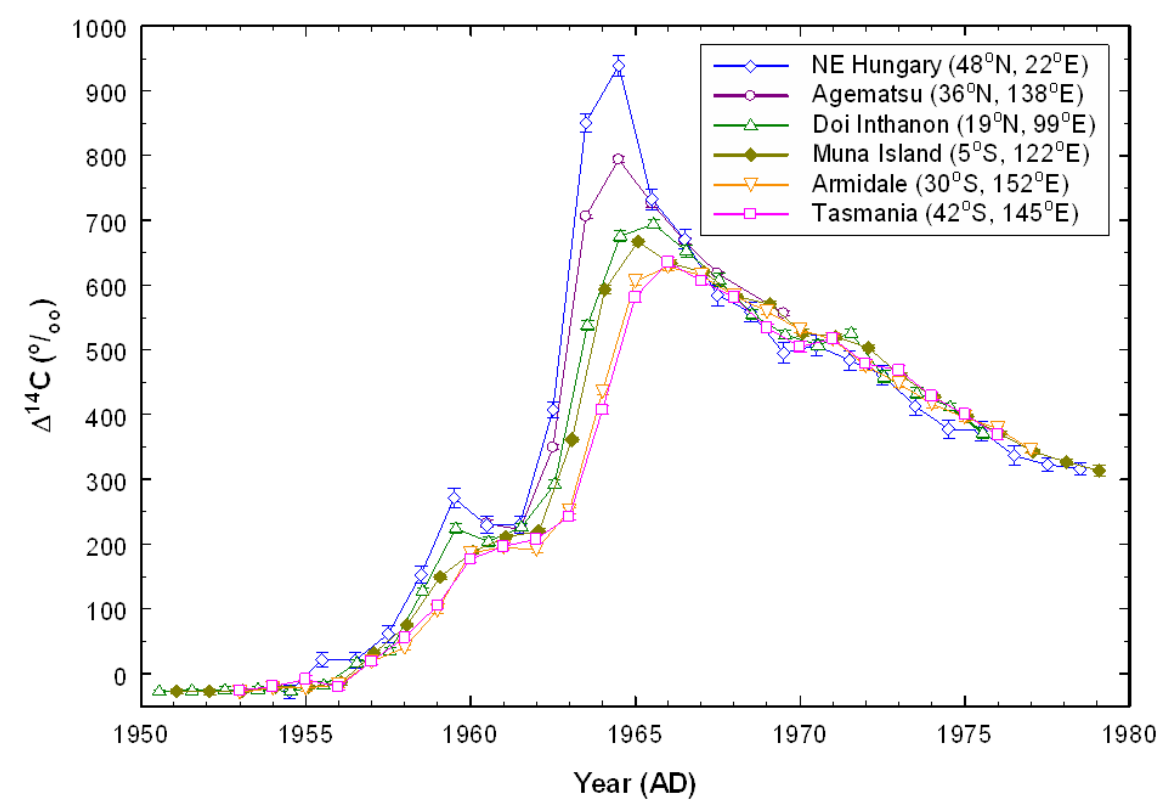

Figure 1 Radiocarbon in tree rings at different locations. Data representing the 4 different zones defined by Hua and Barbetti (2004) include NE Hungary (Hertelendi and Csongor 1982) in NH zone 1; Agematsu, Japan (Muraki et al. 1998) in NH zone 2; Doi Inthanon, Thailand (Hua et al. 2000, 2004) in NH zone 3; and Armidale (Hua et al. 2003) and Tasmania (Hua et al. 2000) from Australia in the SH zone. The new tree-ring data are from Muna Island, Indonesia (Hua et al. 2012b). Error bars are $1 \sigma$.

Most of the atmospheric nuclear tests were carried out in the Northern Hemisphere (NH), resulting in a large ${ }^{14} \mathrm{C}$ gradient in the troposphere (between north and south, and between high latitudes and low latitudes) during the early bomb period from the mid-1950s to late 1960 s. This significantly increased the ${ }^{14} \mathrm{C}$ contrast between the regional tropospheric air masses that shaped the spatial distribution of bomb ${ }^{14} \mathrm{C}$ when excess ${ }^{14} \mathrm{C}$ was transferred southwards. Hua and Barbetti $(2004,2007)$ demonstrated that the $\Delta^{14} \mathrm{C}$ levels in the troposphere during the early bomb period were strongly influenced by atmospheric circulation. As a result, the spatial distribution of bomb ${ }^{14} \mathrm{C}$ during this period did not have a simple latitudinal gradient but consisted of 3 different zones in the NH and 1 zone for the whole Southern Hemisphere (SH). With the availability of a new and reliable long record of bomb ${ }^{14} \mathrm{C}$ in teak tree rings from Muna Island, Sulawesi, Indonesia $\left(5^{\circ} \mathrm{S}, 122^{\circ} \mathrm{E}\right)$ located in the SH and north of the mean winter position of the Intertropical Convergence Zone (ITCZ), Hua et al. (2012b) were able to compare this record to those representing the above 4 zones (Figure 1). For most of the time from the mid-1950s to mid-1960s, Muna $\Delta{ }^{14} \mathrm{C}$ values were much higher than those of other SH records due to the influence of the winter Asian monsoon, which carried $\mathrm{NH}$ air masses containing much more ${ }^{14} \mathrm{C}$ than those from the $\mathrm{SH}$ to Muna during the growing season of its tree rings (Hua et al. 2012b). In contrast, Muna $\Delta{ }^{14} \mathrm{C}$ values were significantly lower than those from Doi Inthanon, Thailand, during the above period. These led Hua et al. (2012b) to suggest a revision of the zonal distribution of bomb ${ }^{14} \mathrm{C}$ during the early bomb period defined by Hua and Barbetti (2004) to include $2 \mathrm{SH}$ zones that are separated by the mean winter position of the ITCZ (Figure 2). 


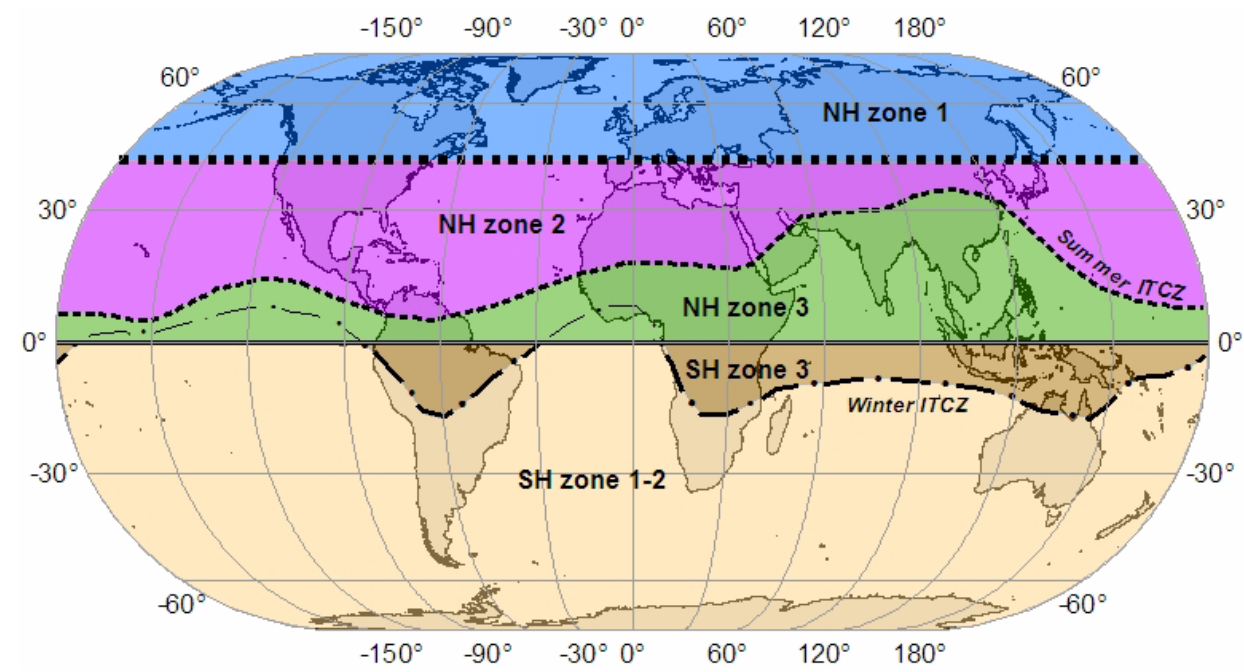

Figure 2 World map showing zonal atmospheric bomb ${ }^{14} \mathrm{C}$. The mean positions of the summer and winter ITCZ are adapted from Linacre and Geerts (1997).

Figure 1 shows a large ${ }^{14} \mathrm{C}$ gradient in the troposphere between 1955 and the late 1960 s, indicating 5 different ${ }^{14} \mathrm{C}$ levels: 3 in the $\mathrm{NH}$ (NH zones 1, 2, and 3) and 2 in the SH (SH zones 3 and 1-2). The highest tropospheric ${ }^{14} \mathrm{C}$ during this period was in $\mathrm{NH}$ zone 1 , where most of the excess ${ }^{14} \mathrm{C}$ was injected from the stratosphere to the troposphere (Nydal and Gislefoss 1996). The level of tropospheric ${ }^{14} \mathrm{C}$ decreased from north to south as the excess ${ }^{14} \mathrm{C}$ was transferred southwards by atmospheric circulation, with $\mathrm{NH}$ zones 1 and 2 separated by the Ferrel cell-Hadley cell boundaries, and $\mathrm{NH}$ zones 2 and 3 by the mean summer position of the ITCZ (Figure 2). As excess ${ }^{14} \mathrm{C}$ was transferred to the tropics, the seasonally switching monsoons mixed air masses from the $\mathrm{NH}$ with those from the $\mathrm{SH}$, which resulted in lower ${ }^{14} \mathrm{C}$ levels for $\mathrm{NH}$ zone 3 and higher ${ }^{14} \mathrm{C}$ levels for $\mathrm{SH}$ zone 3 compared to those at similar latitudes in the $\mathrm{NH}$ and $\mathrm{SH}$, respectively. The spatial distribution of bomb ${ }^{14} \mathrm{C}$ in the $\mathrm{SH}$ should probably consist of 3 zones similar to those for the $\mathrm{NH}$. However, the ${ }^{14} \mathrm{C}$ excess became diffused after it was transported over SH zone 3 and the broad and seasonally moving ITCZ (Hua et al. 1999, 2003). As a consequence, the atmospheric ${ }^{14} \mathrm{C}$ level of the region south of the winter ITCZ was almost uniform and significantly lower than that of SH zone 3 (Figure 1). We therefore consider this region as only 1 zone (instead of 2 zones) for the early bomb period and designate it as SH zone 1-2 (Figure 2). According to Wang (2009), for the modern timescale the ITCZ in the Atlantic and the eastern Pacific is always located north of the Equator with only minor seasonal shifts, while the ITCZ over the western Pacific, the Indian Ocean, Africa and continental South America migrates seasonally far away from the Equator. Therefore, SH zone 3 is not defined for the Atlantic and the eastern Pacific (Figure 2).

The boundary between NH zone 1 and $\mathrm{NH}$ zone 2 shown in Figure 2 is not accurately determined due to the limited spatial extent of ${ }^{14} \mathrm{C}$ records currently available. According to Hua and Barbetti (2004), this boundary around $40^{\circ} \mathrm{N}$ may vary in latitude from one place to another. In particular, this boundary has to be south of China Lake $\left(36^{\circ} \mathrm{N}, 118^{\circ} \mathrm{W}\right)$ but north of Santiago de Compostela $\left(42^{\circ} \mathrm{N}\right.$, $8^{\circ} \mathrm{W}$ ). In Figure 2, the Equator was used as the boundary between NH zone 3 and SH zone 3 or SH zone 1-2. This is because vegetation in these zones grows most vigorously during different times of the year: boreal summers for NH zone 3 and austral summers for SH zones 3 and 1-2. One may argue that the above growing periods of vegetation are correct for the seasonal tropics (from $\sim 5^{\circ} \mathrm{N}$ 
to the summer ITCZ, and from $\sim 5^{\circ} \mathrm{S}$ to the winter ITCZ), but cannot apply to the aseasonal tropics between $\sim 5^{\circ} \mathrm{N}$ and $\sim 5^{\circ} \mathrm{S}$ where rainfall occurs and vegetation grows almost all year round (McGregor and Nieuwolt 1998). However, there are no ${ }^{14} \mathrm{C}$ records currently available for the aseasonal tropics for a better determination of the boundary between NH zone 3 and SH zone 3 .

Bomb ${ }^{14} \mathrm{C}$ approached a global equilibrium in the late 1960s (Telegadas 1971; Manning et al. 1990) and since 1973 there have been similar ${ }^{14} \mathrm{C}$ values in all locations as zonal $\Delta{ }^{14} \mathrm{C}$ levels overlap with each other within $1 \sigma$ uncertainties (see Table S1 in the online Supplementary Material).

\section{DATA SETS USED FOR THE COMPILATION}

Similar to Hua and Barbetti (2004), our compilation of atmospheric ${ }^{14} \mathrm{C}$ was based on comprehensive and reliable ${ }^{14} \mathrm{C}$ data derived from atmospheric samples and tree rings. Only data sets that were not strongly influenced by local combustion of fossil fuel were chosen. This includes the data sets used in the compilation of Hua and Barbetti (2004), and atmospheric records and tree-ring ${ }^{14} \mathrm{C}$ data from clean-air sites that have recently been made available such as Point Barrow $\left(71^{\circ} \mathrm{N}, 157^{\circ} \mathrm{W}\right)$, Hawaii $\left(20^{\circ} \mathrm{N}, 156^{\circ} \mathrm{W}\right)$, Cape Matatula $\left(14^{\circ} \mathrm{S}, 171^{\circ} \mathrm{W}\right)$, and the South Pole $\left(90^{\circ} \mathrm{S}, 25^{\circ} \mathrm{W}\right)$ from Graven et al. (2012b); Jungfraujoch $\left(46^{\circ} \mathrm{N}, 8^{\circ} \mathrm{E}\right.$; Levin and Kromer 2004$)$; Niepołomice $\left(50^{\circ} \mathrm{N}\right.$, $20^{\circ} \mathrm{E}$; Rakowski et al. 2013); Niwot Ridge $\left(40^{\circ} \mathrm{N}, 106^{\circ} \mathrm{W}\right.$; Turnbull et al. 2007); and Muna Island $\left(5^{\circ} \mathrm{S}, 122^{\circ} \mathrm{E}\right.$; Hua et al. $\left.2012 \mathrm{~b}\right)$.

As one of the aims of the present paper is to compile tropospheric ${ }^{14} \mathrm{C}$ data for age calibration, our criterion for including an atmospheric or tree-ring record that is slightly influenced by fossil fuel burning is that the dilution effect for that record is not larger than the typical $1 \sigma$ uncertainty of $3-$ $7 \%$ associated with ${ }^{14} \mathrm{C}$ analysis of terrestrial samples growing during the last $60 \mathrm{yr}$. The Schauinsland $\left(48^{\circ} \mathrm{N}, 8^{\circ} \mathrm{E}\right.$; Levin and Kromer 2004$)$ atmospheric record is slightly influenced by local/ regional fossil-fuel $\mathrm{CO}_{2}$ emissions. The long-term mean of ${ }^{14} \mathrm{C}$-free fossil- fuel $\mathrm{CO}_{2}$ contribution to this record is $1.4 \mathrm{ppm}$ ( $1 \mathrm{ppm}$ in summer and $1.7 \mathrm{ppm}$ in winter) for the period 1986-2001, which is equivalent to a dilution effect of $\sim 4 \%$ (Levin et al. 2003). Thus, the Schauinsland record was included in our compilation. The Kasprowy Wierch $\left(49^{\circ} \mathrm{N}, 20^{\circ} \mathrm{E}\right)$ atmospheric record is also slightly influenced by fossil-fuel burning with a mean fossil $\mathrm{CO}_{2}$ contribution of $\sim 1 \mathrm{ppm}$ in summer and 3$4 \mathrm{ppm}$ in winter for the period late 2007-2009 (Zimnoch et al. 2012). Such contamination is equivalent to a dilution effect of $\sim 3 \%$ in summer and $8-11 \%$ in winter. Based on the above criterion, only ${ }^{14} \mathrm{C}$ data during summer for Kasprowy Wierch were used for our compilation. Tree-ring ${ }^{14} \mathrm{C}$ data from Obrigheim $\left(49^{\circ} \mathrm{N}, 9^{\circ} \mathrm{E}\right)$ are influenced by local/regional combustion of fossil fuel with a mean dilution effect of 15\% for 1967-1982 (Levin et al. 1985). Therefore, this tree-ring record was excluded from our compilation. All ${ }^{14} \mathrm{C}$ records including atmospheric $\mathrm{CO}_{2}$ samples and tree rings employed for the reconstruction of summer and monthly ${ }^{14} \mathrm{C}$ data sets are shown in Table 1.

\section{COMPILED SUMMER ${ }^{14} \mathrm{C}$ DATA SETS}

We present in this section the compilation of data sets for zonal, hemispheric, and global ${ }^{14} \mathrm{C}$ levels for the period 1950-2010. These data sets represent atmospheric ${ }^{14} \mathrm{C}$ during summer months only (May-August for the NH and November-February for the $\mathrm{SH}$ ). This approach has a clear advantage because it allows an extension of the atmospheric ${ }^{14} \mathrm{C}$ records, using tree-ring ${ }^{14} \mathrm{C}$ data when atmospheric ${ }^{14} \mathrm{C}$ data are sparse (e.g. the pre-bomb and early bomb period during the $1950 \mathrm{~s}$ ). 


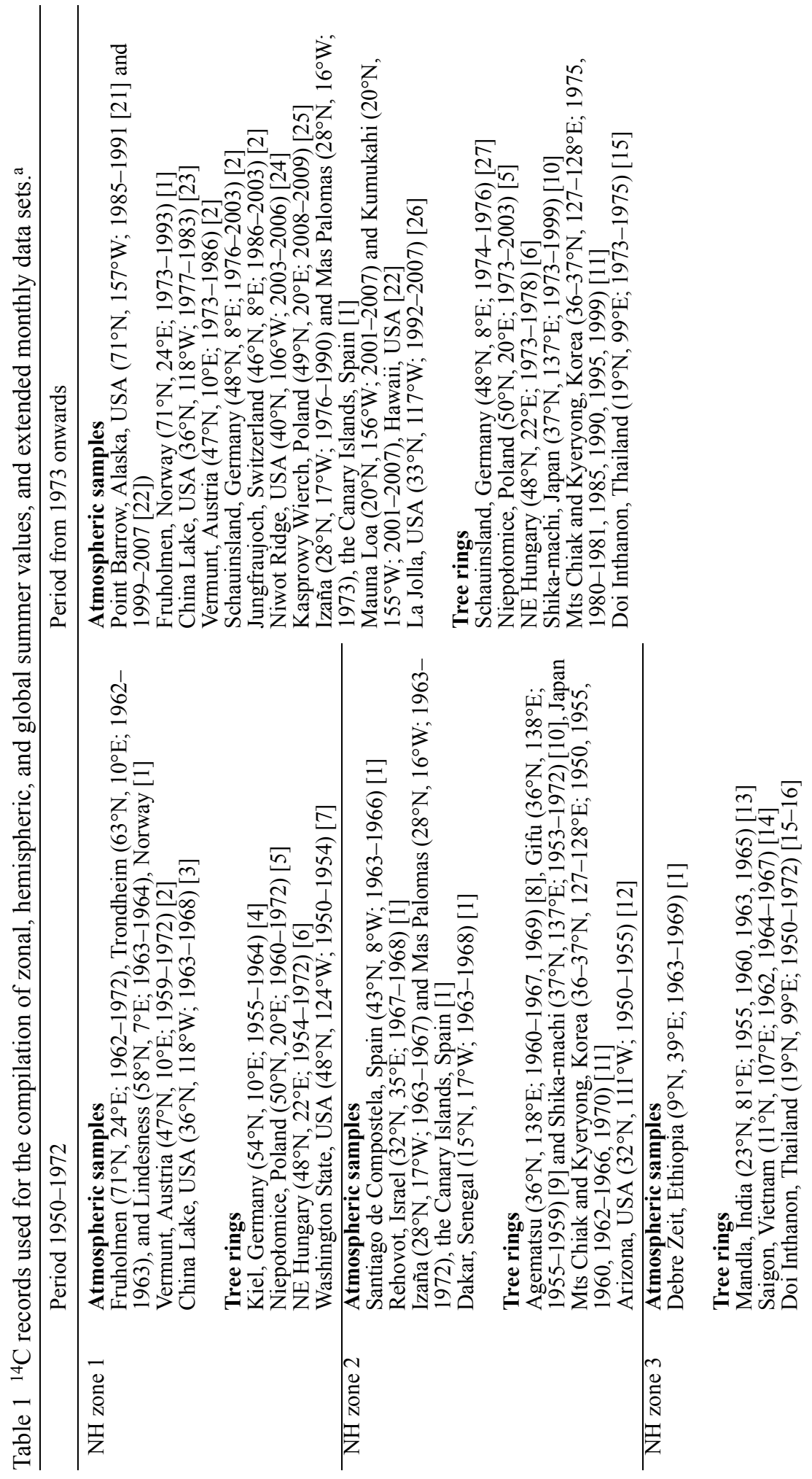




\section{Q Hua et al.}

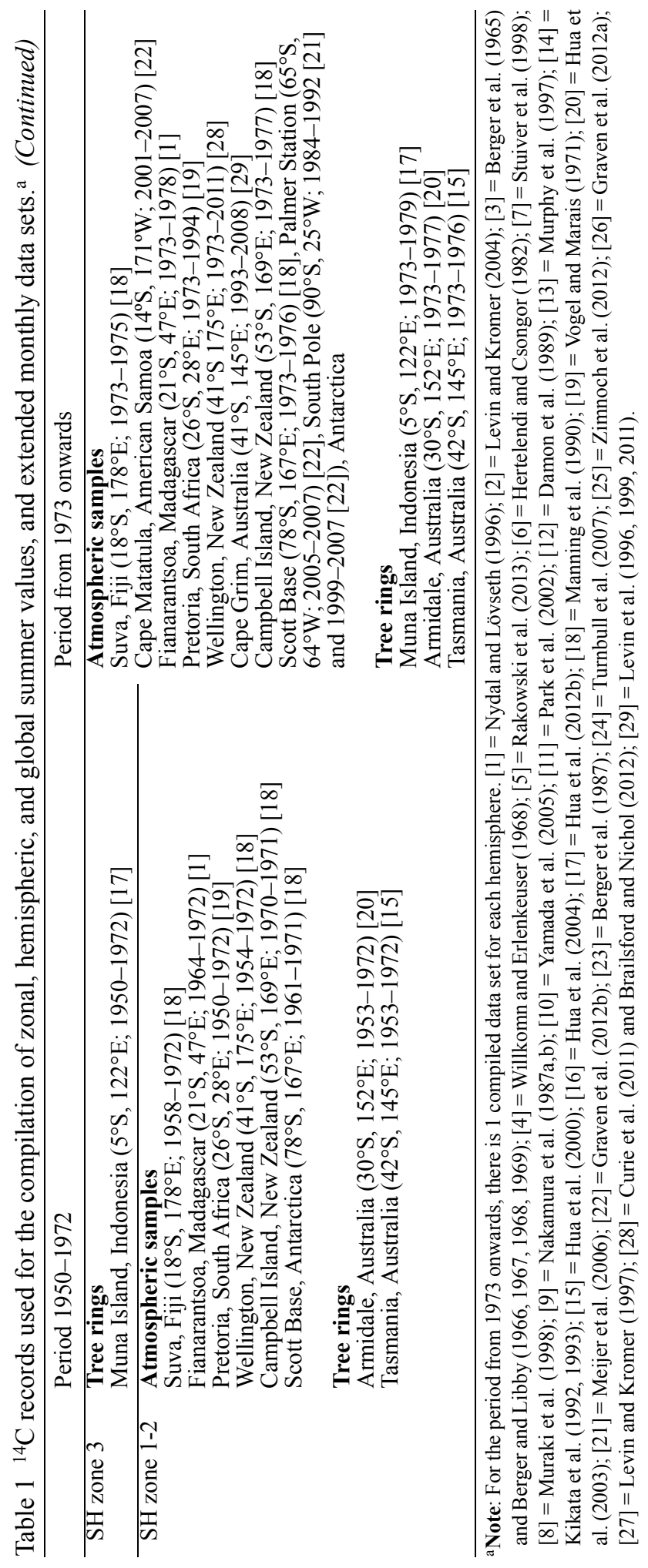




\section{Data Sets for the Northern Hemisphere}

For the period $1950-1972,3$ separate data sets of atmospheric ${ }^{14} \mathrm{C}$ were compiled for the $\mathrm{NH}(\mathrm{NH}$ zones 1,2, and 3). As there have been similar $\Delta{ }^{14} \mathrm{C}$ values between locations from 1973 onwards as mentioned above, we compiled only 1 data set for the $\mathrm{NH}$ for this period.

For an atmospheric ${ }^{14} \mathrm{C}$ record, the mean value for summer months (May-August) for a particular year was calculated only if there were data available for at least 3 out of 4 months for the season. The summer mean values for the atmospheric record are weighted averages based on the ${ }^{14} \mathrm{C}$ uncertainty and on the sampling duration of an individual sample (if the latter was available). The uncertainty associated with the summer mean value is the larger of the error of the mean and the standard error. We chose the standard error rather than the standard deviation here because the former value was usually comparable with tree-ring ${ }^{14} \mathrm{C}$ uncertainties. This approach is necessary to produce unbiased weighted zonal mean values in the next step of calculation when mean values of atmospheric records and tree-ring data were used.

The average summer value for a particular zone in the $\mathrm{NH}$ in a particular year is the weighted average value based on the uncertainty associated with the summer mean of the individual record. The uncertainty associated with the average summer value is the larger of the error of the mean and the standard deviation. These criteria and methods were also employed for calculation of Southern Hemispheric and global data sets.

Weighted summer mean values for the NH for 1950-1972 were calculated from the 3 zonal summer means, with weights consisting of uncertainties associated with the zonal summer value and zonal surface area. The percentages of zonal surface areas within the $\mathrm{NH}$ for $\mathrm{NH}$ zones 1,2, and 3 were taken as $17 \%, 46 \%$, and $37 \%$, respectively.

Compiled zonal atmospheric $\Delta^{14} \mathrm{C}$ data sets for $\mathrm{NH}$ zones 1, 2, and 3 for the boreal summer season (May-August) for the period 1950-2010 are presented in Table S2a in the online Supplementary Material and depicted in Figure 3. These zonal data sets together with individual ${ }^{14} \mathrm{C}$ records available in each zone are shown in Figures S1-S3 in the online Supplementary Material. The compiled hemispheric $\Delta^{14} \mathrm{C}$ data set for the NH for boreal summers (May-August) for the period 1950-2010 is also presented in Table S2a and illustrated in Figure 4.

\section{Data Sets for the Southern Hemisphere}

For the period 1950-1972, 2 separate data sets of atmospheric ${ }^{14} \mathrm{C}$ were compiled for the $\mathrm{SH}(\mathrm{SH}$ zones 3 and 1-2). For the period from 1973 onwards, only 1 data set for the SH was compiled. We employed the same methods that were used for the NH for the calculation of the summer mean values for SH zones 3 and 1-2, and the whole of the SH for 1950-2011. The relative percentages of zonal surface areas for SH zones 3 and $1-2$ were taken as $15 \%$ and $85 \%$, respectively, when calculating SH summer averages for 1950-1972.

Compiled zonal atmospheric $\Delta^{14} \mathrm{C}$ data sets for SH zones 3 and 1-2 for the austral summer season (November-February) for the period 1950-2011 are presented in Table S2b in the online Supplementary Material and also illustrated in Figure 3. These zonal data sets together with individual ${ }^{14} \mathrm{C}$ records available in each zone are shown in Figures S4-S5 in the online Supplementary Material. The compiled hemispheric $\Delta^{14} \mathrm{C}$ data set for the SH for austral summers (November-February) for the period 1950-2011 is also presented in Table S2b and illustrated in Figure 4. 


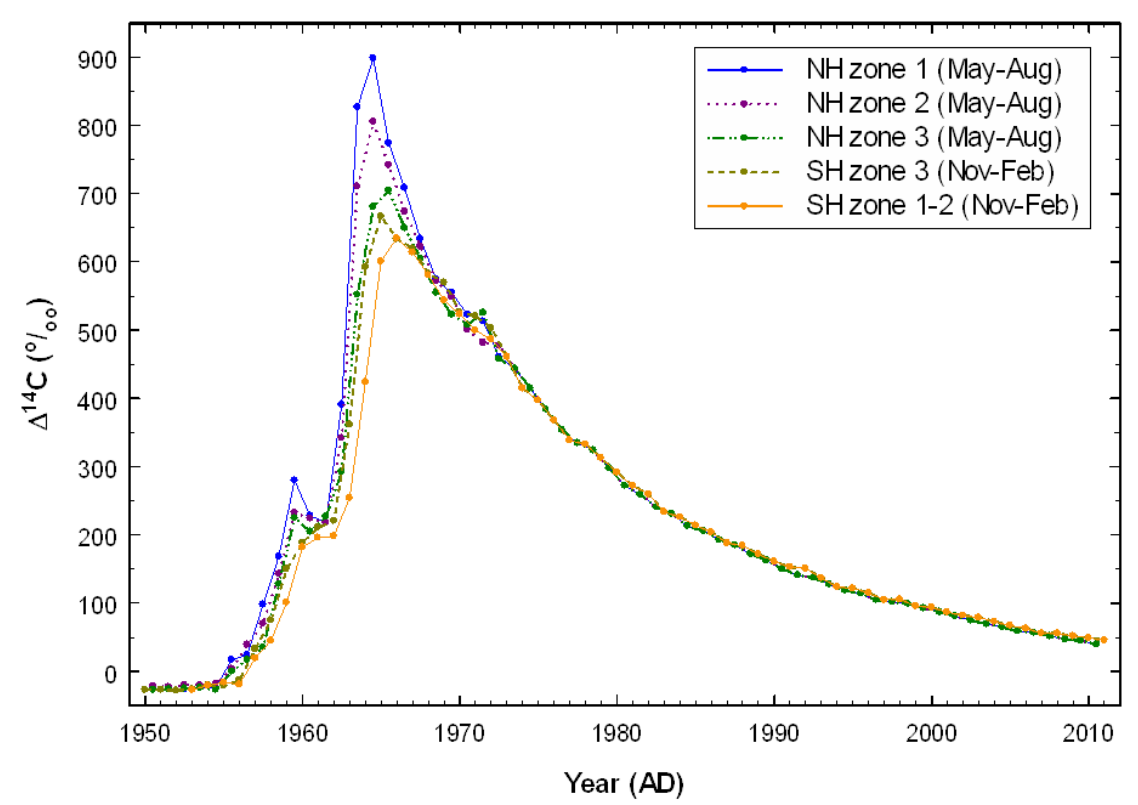

Figure 3 Compiled summer atmospheric ${ }^{14} \mathrm{C}$ curves for 5 different zones ( $\mathrm{NH}$ zone 1, $\mathrm{NH}$ zone 2, $\mathrm{NH}$ zone 3, SH zone 3, and SH zone 1-2). The compiled data sets are presented in Tables S2a-b.

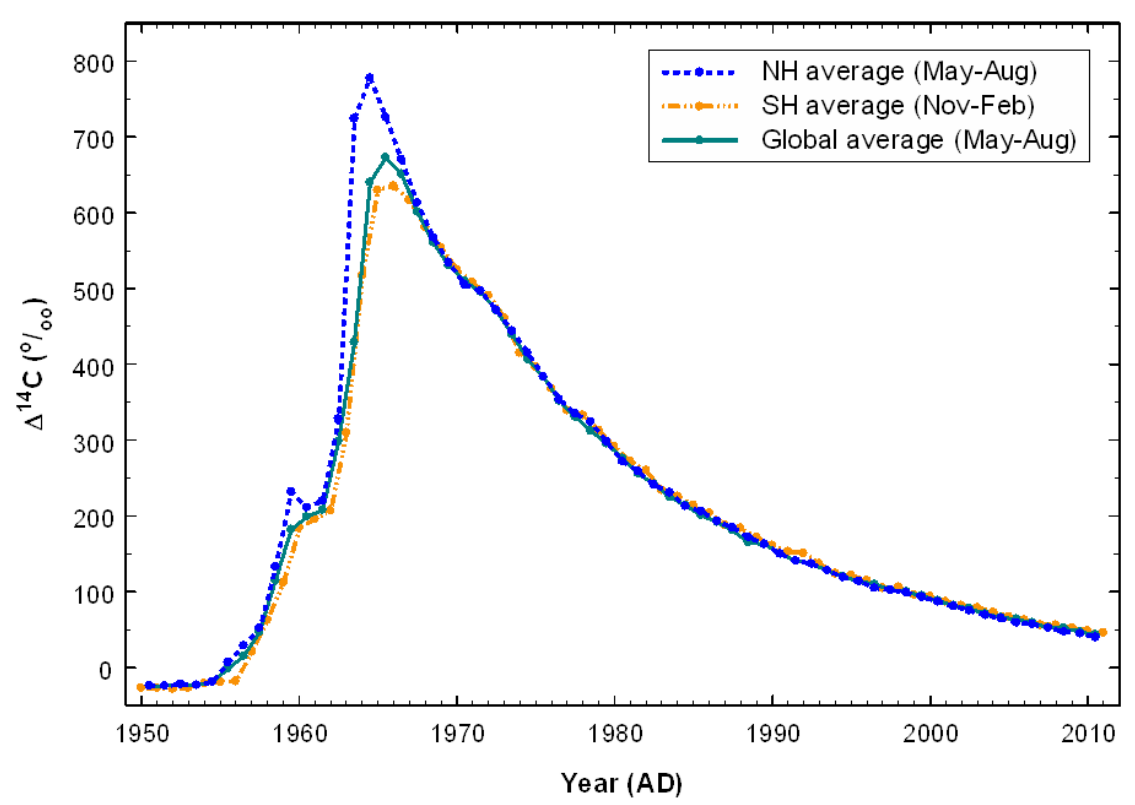

Figure 4 Compiled summer hemispheric and global ${ }^{14} \mathrm{C}$ curves. The compiled data sets are presented in Tables S2a-c. 


\section{Global Atmospheric ${ }^{14} \mathrm{C}$ Data Set}

The compiled data sets for the NH (Table S2a) and the SH (Table S2b) have different timespans: the middle of a calendar year for the $\mathrm{NH}$ and the beginning of the following year for the $\mathrm{SH}$. We therefore compiled zonal $\Delta^{14} \mathrm{C}$ values for the $\mathrm{SH}$ for the middle of a calendar year. When compiled zonal $\Delta^{14} \mathrm{C}$ values for the $\mathrm{SH}$ for boreal summers (May-August) were not available, we estimated these values by linear interpolation of the compiled zonal data sets for the SH for austral summers (November-February) presented in Table S2b. The zonal values for the SH for boreal summers (May-August) are presented in Table S2c in the online Supplementary Material.

As a result of the large ${ }^{14} \mathrm{C}$ gradient in the northern troposphere for the early bomb period, the uncertainties associated with the compiled hemispheric average values for the $\mathrm{NH}$ are usually larger than those for the SH for boreal summers for that period (Hua and Barbetti 2004). The global weighted means for boreal summers for 1950-1972 would therefore be biased and close to the SH averages if the above 2 hemispheric data sets were used for the compilation of the global ${ }^{14} \mathrm{C}$ data.

We therefore compiled the global weighted means for boreal summers for 1950-1972 using the 5 zonal data sets as the uncertainties associated with the 3 zonal values for the $\mathrm{NH}$ for boreal summers (see Tables S2a and S2c) were almost comparable to those associated with the 2 corresponding zonal values for the SH (see Table S2c). The percentages of zonal surface areas for NH zones 1, 2, and 3, and SH zones 3 and 1-2 were taken as $8.5 \%, 23 \%, 18.5 \%, 7.5 \%$, and $42.5 \%$, respectively.

For the period 1973 onwards, the global mean values were calculated from 2 hemispheric data sets, the $\mathrm{NH}$ and SH means for boreal summers, which are presented in Table S2c. The compiled global average values for $1950-2010$ are also reported in Table S2c. Global ${ }^{14} \mathrm{C}$ mean values for boreal summer months (May-August) for the period 1950-2010 are also shown in Figure 4.

\section{COMPILED (EXTENDED) MONTHLY ${ }^{14} \mathrm{C}$ DATA SETS}

Five compiled zonal data sets are presented in this section. The data sets were compiled mainly from monthly mean values derived from atmospheric ${ }^{14} \mathrm{C}$ records. As most of those atmospheric ${ }^{14} \mathrm{C}$ records are available only from the late 1950 s or early 1960s onwards, these compiled data sets were then extended to 1950 using compiled summer ${ }^{14} \mathrm{C}$ data based on tree rings.

The calculation of zonal monthly mean values consisted of 2 stages: calculation of monthly values for each atmospheric record and calculation of zonal monthly means. For each month, the monthly value for each record was the weighted mean of a number of individual samples if more than 1 sample was available for that month. The weights for calculating monthly values were the ${ }^{14} \mathrm{C}$ uncertainties and the sampling duration (if available) of individual samples. The uncertainty associated with a monthly mean was the larger value of the error of the mean and the standard error. The monthly mean value for a particular zone in a particular year is the weighted average value based on the uncertainty associated with the monthly mean of the individual record. The uncertainty associated with the zonal monthly mean value is the larger of the error of the mean and the standard deviation.

The ${ }^{14} \mathrm{C}$ records from atmospheric $\mathrm{CO}_{2}$ samples employed for the reconstruction of zonal monthly ${ }^{14} \mathrm{C}$ for the $\mathrm{NH}$ and $\mathrm{SH}$ are shown in Table 1. For $\mathrm{NH}$ zone 1, the compiled monthly data, from February 1959 to August 2009, were extended to mid-1950 using the compiled summer data for $\mathrm{NH}$ zone 1 for 1950-1958 reported in Table S2a. These summer (May-August) values were based on tree-ring ${ }^{14} \mathrm{C}$. 
Regarding NH zone 2, the compiled monthly data of March 1963-August 2009 were extended back to mid-1950 using the tree-ring-based summer data for NH zone 2 for 1950-1962 reported in Table S2a. For NH zone 3, the compiled monthly data are from May 1963 to July 1969 and January 1973 to August 2009. The tree-ring-based summer ${ }^{14} \mathrm{C}$ data for $\mathrm{NH}$ zone 3 for $1950-1962$ and 1970 1972, reported in Table S2a, were used to fill the gap and extend the monthly data back to mid-1950.

Regarding SH zone 3, the compiled monthly data set of January 1973-March 2011 was extended to 1950 using the tree-ring-based summer (November-February) data for SH zone 3 for 1950-1972 reported in Table S2b.

For SH zone 1-2, the compiled monthly data set was from June 1950 to March 2011. However, as the data were sparse for the pre-bomb period, we also included the tree-ring-based summer (November-February) ${ }^{14} \mathrm{C}$ data for SH zone 1-2 for 1953-1954, which are reported in Table S2b.

The extended monthly data for NH zones 1, 2, and 3 (1950-August 2009) and SH zones 3 and 1-2 (1950-March 2011), in $\Delta^{14} \mathrm{C}$ and $\mathrm{F}^{14} \mathrm{C}$ (Reimer et al. 2004), are presented in Tables S3a-e in the online Supplementary Material. Because these extended monthly ${ }^{14} \mathrm{C}$ data sets are used for age calibration, Figure 5 shows these compiled data sets in $\mathrm{F}^{14} \mathrm{C}$ rather than $\Delta^{14} \mathrm{C}$ (an age-corrected value as mentioned above).

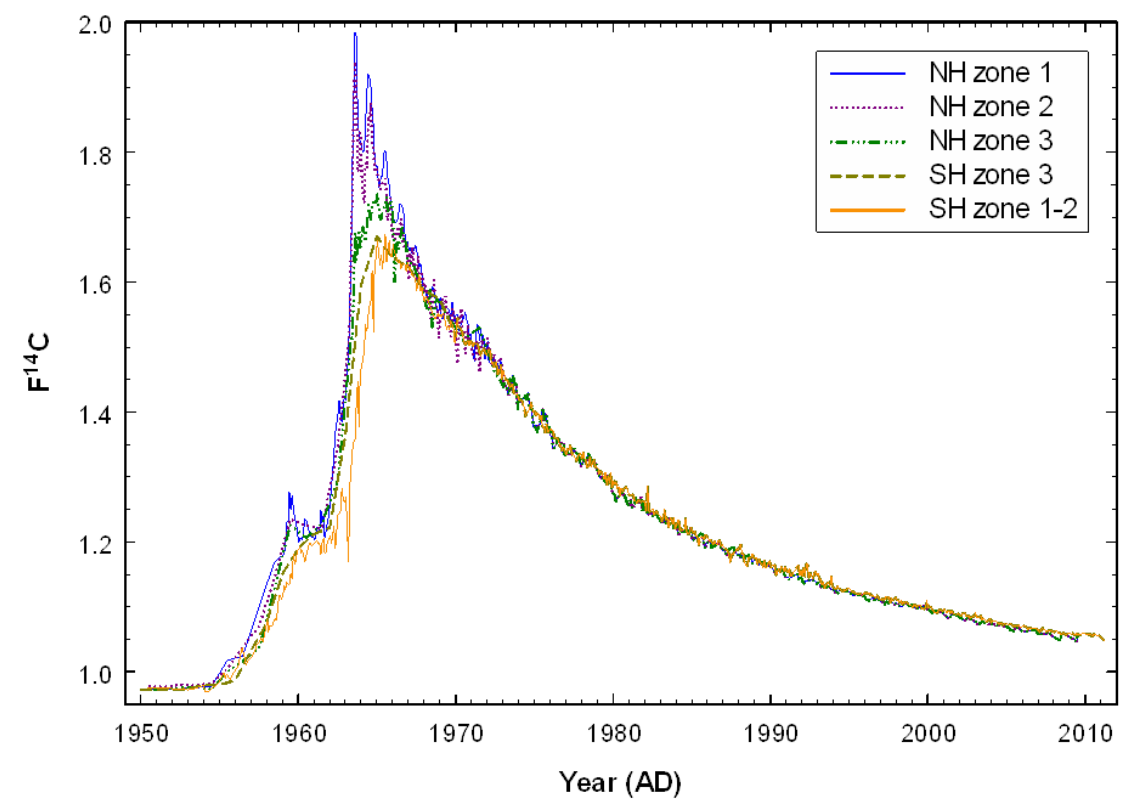

Figure 5 Compiled (extended) monthly atmospheric ${ }^{14} \mathrm{C}$ curves for 5 different zones (NH zone 1, $\mathrm{NH}$ zone 2, NH zone 3, SH zone 3, and SH zone 1-2). The compiled data sets are reported in Tables S3a-e (online Supplementary Material).

\section{COMPARISON BETWEEN THE NEWLY COMPILED DATA AND THOSE OF HUA AND BAR- BETTI (2004)}

There are 3 main differences between the data of Hua and Barbetti (2004) and the data presented herein: (a) The new compilation of tropospheric ${ }^{14} \mathrm{C}$ in this paper contains 5 zones ( 3 in the $\mathrm{NH}$ and 2 in the $\mathrm{SH}$ ) compared to 4 zones ( 3 in the $\mathrm{NH}$ and 1 for the $\mathrm{SH}$ ) for the compilation of Hua and Bar- 
betti (2004). That means SH zone 3, shown in Figure 2, is a new zone; (b) The compiled data in this study cover the periods 1950-2010 and 1950-2011 for the NH and SH, respectively, while the respective periods in Hua and Barbetti (2004) are 1955-1999 and 1955-2001. In other words, this new compilation extended the data $5 \mathrm{yr}$ into the pre-bomb period and $\sim 10 \mathrm{yr}$ into more recent times; and (c) The period of which 1 data set of each hemisphere was compiled is from 1973 onwards for this compilation and from 1970 onwards for that of Hua and Barbetti (2004).

\section{Summer ${ }^{14} \mathrm{C}$ Data Sets}

For the overlapping periods (1955-1999 for the NH and 1955-2001 for the SH), the new compiled zonal data agree well with those of Hua and Barbetti (2004), with 95\% of the data agreeing within $1 \sigma$ uncertainties and most of the remainder within $2 \sigma$ uncertainties. Similarly, the new compiled hemispheric and global data have a good concordance with the 2004 data, with $97 \%$ of the data agreeing within $1 \sigma$ uncertainties and the remaining data within $2 \sigma$ uncertainties.

\section{Extended Monthly ${ }^{14} \mathrm{C}$ Data Sets}

The overlapping periods of the compiled extended monthly data sets (from this study and from Hua and Barbetti [2004]) are mid-1955 to January 1997 for the NH zones, and early 1955 to December 1996 for SH zone 1-2. In these periods, the new compiled extended monthly data agree well with those of Hua and Barbetti (2004), with $99 \%$ of the data agreeing within $1 \sigma$ uncertainties and the remainder within $2 \sigma$ uncertainties.

\section{CONCLUSION}

A new comprehensive compilation of tropospheric ${ }^{14} \mathrm{C}$ for the last $60 \mathrm{yr}(1950-2010)$ is now available. The compiled data sets cover $\sim 5$ yr before the influence of bomb ${ }^{14} \mathrm{C}$, the atmospheric bombdetonation period from the mid-1950s until 1962, the rise of tropospheric ${ }^{14} \mathrm{C}$ in the mid-1960s as significant excess bomb ${ }^{14} \mathrm{C}$ was injected from the stratosphere, and the post-bomb era up to very recent times. The new compilation consists of summer and mostly monthly data sets for use in carbon cycle studies and dating of recent, short-lived terrestrial organic materials, respectively. The extended monthly data sets are used in the CALIBomb (http://calib.qub.ac.uk/CALIBomb/) and OxCal (http://c14.arch.ox.ac.uk) software packages for age calibration. The Supplemental Material accompanying the online version of this article can be found at https://journals.uair.arizona.edu/ index.php/radiocarbon/article/view/16177.

\section{ACKNOWLEDGMENTS}

We thank S Hankin for the preparation of Figure 2, G Brailsford and S Nichol for giving us permission to use the NIWA Baring Head (Wellington) data from June 2005 to March 2011, K Rozanski and T Kuc for their provision of tabulated data for Kasprowy Wierch, and Y Yamada for the clarification of Shika-machi data for 1957-1958. We also thank our colleagues in atmospheric, tree-ring, and ${ }^{14} \mathrm{C}$ studies for discussions and comments over many years. Three anonymous reviewers provided helpful, critical, and constructive comments that improved the manuscript.

\section{REFERENCES}

Alkass K, Buchholz BA, Druid H, Spalding KL. 2011. Analysis of ${ }^{14} \mathrm{C}$ and ${ }^{13} \mathrm{C}$ in teeth provides precise birth dating and clues to geographical origin. Forensic Science International 209(1-3):34-41.
Berger R, Libby WF. 1966. UCLA radiocarbon dates V. Radiocarbon 8:467-97.

Berger R, Libby WF. 1967. UCLA radiocarbon dates VI. Radiocarbon 9:477-504. 
Berger R, Libby WF. 1968. UCLA radiocarbon dates VIII. Radiocarbon 10(2):402-16.

Berger R, Libby WF. 1969. UCLA radiocarbon dates IX. Radiocarbon 11(1):194-209.

Berger R, Fergusson GJ, Libby WF. 1965. UCLA radiocarbon dates IV. Radiocarbon 7:336-71.

Berger R, Jackson TB, Michael R, Suess HE. 1987. Radiocarbon content of tropospheric $\mathrm{CO}_{2}$ at China Lake, California 1977-1983. Radiocarbon 29(1):18-23.

Bhardwaj RD, Curtis MA, Spalding KL, Buchholz BA, Fink D, Björk-Eriksson T, Nordborg C, Gage FH, Druid H, Eriksson PS, Frisén J. 2006. Neocortical neurogenesis in humans is restricted to development. Proceedings of the National Academy of Sciences of the USA 103(33):12,564-8.

Bowman DMJS, Prior LD, Tng D, Hua Q, Brodribb TJ. 2011. Continental-scale climatic drivers of growth ring variability in an Australian conifer. Trees - Structure and Function 25(5):925-34.

Brailsford G, Nichol S. 2012. NIWA Baring Head (Wellington) $\Delta^{14} \mathrm{C}$ data from December 1954 to March 2011, World Data Centre for Greenhouse Gases. Available at URL: http://ds.data.jma.go.jp/gmd/wdcgg/cgi-bin/wdcgg/download.cgi?indeNIWA\&para= 14CO2\&param $=200802010003 \&$ select $=$ inventory.

Broecker WS, Peng TH, Engh R. 1980. Modeling the carbon system. Radiocarbon 22(3):565-98.

Bruun S, Six J, Jensen LS, Paustian K. 2005. Estimating turnover of soil organic carbon fractions based on radiocarbon measurements. Radiocarbon 47(1):99-113.

Buchholz BA, Spalding KL. 2010. Year of birth determination using radiocarbon dating of dental enamel. Surface and Interface Analysis 42(5):398-401.

Clarke LJ, Robinson SA, Hua Q, Ayre DJ, Fink D. 2012. Radiocarbon bomb spike reveals biological effects of Antarctic climate change. Global Change Biology 18(1):301-10.

Currie KI, Brailsford G, Nichol S, Gomez A, Sparks R, Lassey KR, Riedel K. 2011. Tropospheric ${ }^{14} \mathrm{CO}_{2}$ at Wellington, New Zealand: the world's longest record. Biogeochemistry 104(1-3):5-22.

Damon PE, Cheng S, Linick TW. 1989. Fine and hyperfine structure in the spectrum of secular variations of atmospheric ${ }^{14}$ C. Radiocarbon 31(3):704-18.

Druffel ERM. 1997. Geochemistry of corals: proxies of past ocean chemistry, ocean circulation, and climate. Proceedings of the National Academy of Sciences of the USA 94(16):8354-61.

Druffel EM, Suess HE. 1983. On the radiocarbon record in banded corals: exchange parameters and net transport of ${ }^{14} \mathrm{CO}_{2}$ between atmosphere and surface ocean. Journal of Geophysical Research 88(C2):1271-80.

Ehleringer JR, Casale JF, Barnette JE, Xu X, Lott MJ, Hurley J. 2012. ${ }^{14} \mathrm{C}$ analyses quantify time lag between coca leaf harvest and street-level seizure of cocaine. Forensic Science International 214(1-3):7-12.

English NB, Dettman DL, Williams DG. 2010. A 26-year stable isotope record of humidity and El Niño-enhanced precipitation in the spines of saguaro cactus, Carnegiea gigantea. Palaeogeography, Palaeoclimatology, Palaeoecology 293(1-2):108-19.

Fellner J, Rechberger H. 2009. Abundance of ${ }^{14} \mathrm{C}$ in biomass fractions of wastes and solid recovered fuels. Waste Management 29(5):1495-503.

Fichtler E, Clark DA, Worbes M. 2003. Age and longterm growth of trees in an old-growth tropical rain forest, based on analyses of tree rings and ${ }^{14} \mathrm{C}$. Biotropica 35(3):306-17.

Graven HD, Guilderson TP, Keeling RF. 2012a. Observations of radiocarbon in $\mathrm{CO}_{2}$ at $\mathrm{La}$ Jolla, California, USA 1992-2007: analysis of the long-term trend. Journal of Geophysical Research 117: D02302, doi: 10.1029/2011JD016533.

Graven HD, Guilderson TP, Keeling RF. 2012b. Observations of radiocarbon in $\mathrm{CO}_{2}$ at seven global sampling sites in the Scripps flask network: analysis of spatial gradients and seasonal cycles. Journal of Geophysical Research 117: D02303, doi:10.1029/ 2011JD016535.

Hertelendi E, Csongor E. 1982. Anthropogenic ${ }^{14} \mathrm{C}$ excess in the troposphere between 1951 and 1978 measured in tree rings. Radiochemical and Radioanalytical Letters 56:103-10.

Hodge E, McDonald J, Fischer M, Redwood D, Hua Q, Levchenko V, Waring C, Drysdale R, Fink D. 2011. Using the ${ }^{14} \mathrm{C}$ bomb pulse to date young speleothems. Radiocarbon 53(2):345-57.

Hua Q. 2009. Radiocarbon: a chronological tool for the recent past. Quaternary Geochronology 4(5):378-90.

Hua Q, Barbetti M. 2004. Review of tropospheric bomb radiocarbon data for carbon cycle modeling and age calibration purposes. Radiocarbon 46(3):1273-98.

Hua Q, Barbetti M. 2007. Influence of atmospheric circulation on regional ${ }^{14} \mathrm{CO}_{2}$ differences. Journal of Geophysical Research 112: D19102, doi:10.1029/ 2006JD007898.

Hua Q, Barbetti M, Worbes M, Head J, Levchenko VA. 1999. Review of radiocarbon data from atmospheric and tree ring samples for the period 1945-1997 AD. IAWA Journal 20:261-83.

Hua Q, Barbetti M, Jacobsen GE, Zoppi U, Lawson EM. 2000. Bomb radiocarbon in annual tree rings from Thailand and Tasmania. Nuclear Instruments and Methods in Physics Research B 172(1-4):359-65.

Hua Q, Barbetti M, Zoppi U, Chapman DM, Thomson B. 2003. Bomb radiocarbon in tree rings from northern New South Wales, Australia: implications for dendrochronology, atmospheric transport and air-sea exchange of $\mathrm{CO}_{2}$. Radiocarbon 45(3):431-47.

Hua Q, Barbetti M, Zoppi U. 2004. Radiocarbon in annual tree rings from Thailand during the pre-bomb period, AD 1938-1954. Radiocarbon 46(2):925-32.

Hua Q, McDonald J, Redwood D, Drysdale R, Lee S, Fallon S, Hellstrom J. 2012a. Robust chronological re- 
construction for young speleothems using radiocarbon. Quaternary Geochronology 14:67-80.

Hua Q, Barbetti M, Levchenko VA, D’Arrigo RD, Buckley BM, Smith AM. 2012b. Monsoonal influences on Southern Hemisphere ${ }^{14} \mathrm{CO}_{2}$. Geophysical Research Letters 39: L19806, doi:10.1029/2012GL052971.

Kikata Y, Yonenobu H, Morishita F, Hattori Y. $1992 .{ }^{14} \mathrm{C}$ concentrations in tree stems. Bulletin of the Nagoya University Furukawa Museum 8:41-6. In Japanese.

Kikata Y, Yonenobu H, Morishita F, Hattori Y, Marsoem SN. 1993. ${ }^{14} \mathrm{C}$ concentrations in tree stems I. Mokuzai Gakkaishi 39(3):333-7. In Japanese.

Koarashi J, Atarashi-Andoh M, Ishizuka S, Miura S, Saito T, Hirai K. 2009. Quantitative aspects of heterogeneity in soil organic matter dynamics in a cool-temperate Japanese beech forest: a radiocarbon-based approach. Global Change Biology 15(3):631-42.

Levin I, Hesshaimer V. 2000. Radiocarbon - a unique tracer of global carbon cycle dynamics. Radiocarbon 42(1):69-80.

Levin I, Kromer B. 1997. Twenty years of atmospheric ${ }^{14} \mathrm{CO}_{2}$ observations at Schauinsland station, Germany. Radiocarbon 39(2):205-18.

Levin I, Kromer B. 2004. The tropospheric ${ }^{14} \mathrm{CO}_{2}$ level in mid-latitudes of the Northern Hemisphere (19592003). Radiocarbon 46(3):1261-72.

Levin I, Kromer B, Schoch-Fischer H, Bruns M, Münnich M, Berdau D, Vogel JC, Münnich KO. 1985. 25 years of tropospheric ${ }^{14} \mathrm{C}$ observations in central $\mathrm{Eu}$ rope. Radiocarbon 27(1):1-19.

Levin I, Kromer B, Francey RJ. 1996. Continuous measurements of ${ }^{14} \mathrm{C}$ in atmospheric $\mathrm{CO}_{2}$ at Cape Grim. In: Francey RJ, Dick AL, Derek N, editors. Baseline Atmospheric Program Australia 1994-1995. Melbourne: CSIRO. p 106-7.

Levin I, Kromer B, Francey RJ. 1999. Continuous measurements of ${ }^{14} \mathrm{C}$ in atmospheric $\mathrm{CO}_{2}$ at Cape Grim, 1995-1996. In: Grass JL, Derek N, Tindale NW, Dick AL, editors. Baseline Atmospheric Program Australia 1996. Melbourne: Bureau of Meteorology and CSIRO Atmospheric Research. p 89-90.

Levin I, Kromer B, Schmidt M, Sartorius H. 2003. A novel approach for independent budgeting of fossil fuels $\mathrm{CO}_{2}$ over Europe by ${ }^{14} \mathrm{CO}_{2}$ observations. Geophysical Research Letters 30(23):2194, doi: 10.1029/ 2003 GL018477.

Levin I, Naegler T, Kromer B, Diehl M, Francey RJ, Gomez-Pelaez AJ, Steele LP, Wagenbach D, Weller R, Worthy DE. 2010. Observations and modelling of the global distribution and long-term trend of atmospheric ${ }^{14} \mathrm{CO}_{2}$. Tellus B 62(1):26-46.

Levin I, Kromer B, Steele LP, Porter LW. 2011. Continuous measurements of ${ }^{14} \mathrm{C}$ in atmospheric $\mathrm{CO}_{2}$ at Cape Grim, 1997-2008. In: Derek N, Krummel PB, editors. Baseline Atmospheric Program Australia 2007-2008. Melbourne: Australian Bureau of Meteorology and CSIRO Marine and Atmospheric Research. p 56-9.
Linacre E, Geerts B. 1997. Climates and Weather Explained. London: Routledge.

Lovelock CE, Sorrell B, Hancock N, Hua Q, Swales A. 2010. Mangrove forest and soil development on a rapidly accreting shore in New Zealand. Ecosystems 13(3):437-51.

Lynnerup N, Kjeldsen H, Heegaard S, Jacobsen C, Heinemeier J. 2008. Radiocarbon dating of the human eye lens crystallines reveal proteins without carbon turnover throughout life. PloS ONE 3(1):e1529, doi: 10.1371/journal.pone.0001529.

Manning MR, Lowe DC, Melhuish WH, Sparks RJ, Wallace G, Brenninkmeijer CAM, McGrill RC. 1990. The use of radiocarbon measurements in atmospheric studies. Radiocarbon 32(1):37-58.

McGregor GR, Nieuwolt S. 1998. Tropical Climatology-An Introduction to the Climates of the Low Latitudes. Hoboken: John Wiley.

Meijer HAJ, Pertuisot MH, van der Plicht J. 2006. Highaccuracy ${ }^{14} \mathrm{C}$ measurements for atmospheric $\mathrm{CO}_{2}$ samples by AMS. Radiocarbon 48(3):355-72.

Mohn J, Szidat S, Fellner J, Rechberger H, Quartier R, Buchmann B, Emmenegger L. 2008. Determination of biogenic and fossil $\mathrm{CO}_{2}$ emitted by waste incineration based on ${ }^{14} \mathrm{CO}_{2}$ and mass balances. Bioresource Technology 99(14):6471-9.

Mohn J, Szidat S, Zeyer K, Emmenegger L. 2012. Fossil and biogenic $\mathrm{CO}_{2}$ from waste incineration based on a yearlong radiocarbon study. Waste Management 32(8):1516-20.

Muraki Y, Kocharov G, Nishiyama T, Naruse Y, Murata T, Masuda K, Arslanov KhA. 1998. The new Nagoya radiocarbon laboratory. Radiocarbon 40(1):177-82.

Murphy JO, Lawson EM, Fink D, Hotchkis MAC, Hua Q, Jacobsen GE, Smith AM, Tuniz C. 1997. ${ }^{14}$ C AMS measurements of the bomb pulse in N- and S-hemisphere tropical trees. Nuclear Instruments and Methods in Physics Research B 123(1-4):447-50.

Nakamura T, Nakai N, Ohishi S. 1987a. Applications of environmental ${ }^{14} \mathrm{C}$ measured by AMS as a carbon tracer. Nuclear Instruments and Methods in Physics Research B 29(1-2):355-60.

Nakamura T, Nakai N, Kimura M, Ohishi S, Hattori Y, Kikata Y. 1987b. Variations in ${ }^{14} \mathrm{C}$ concentrations of tree rings (1945-1983). Chikyu-Kagaku (Geochemistry) 21:7-12. In Japanese.

Nakamura T, Kojima S, Ohta T, Nishida M, Rakowski A, Ikeda A, Oda H, Niu E. 2007. Application of AMS ${ }^{14} \mathrm{C}$ measurements to criminal investigations. Journal of Radioanalytical and Nuclear Chemistry 272(2):32732.

Nydal R. 1968. Further investigation on the transfer of radiocarbon in nature. Journal of Geophysical Research 73(12):3617-35.

Nydal R, Gislefoss JS. 1996. Further application of bomb ${ }^{14} \mathrm{C}$ as a tracer in the atmosphere and ocean. Radiocarbon 38(3):389-406.

Nydal R, Lövseth K. 1996. Carbon-14 measurement in 
atmospheric $\mathrm{CO}_{2}$ from Northern and Southern Hemisphere sites, 1962-1993. Carbon Dioxide Information Analysis Center, World Data Center-A for Atmospheric Trace Gases, Oak Ridge National Laboratory, Tennessee.

Oeschger H, Siegenthaler U, Schotterer U, Gugelmann A. 1975. A box diffusion model to study the carbon dioxide exchange in nature. Tellus 27(2):168-92.

Palstra SWL, Meijer HAJ. 2010. Carbon-14 based determination of the biogenic fraction of industrial $\mathrm{CO}_{2}$ emissions - application and validation. Bioresource Technology 101(10):3702-10.

Park JH, Kim JC, Cheoun MK, Kim IC, Youn M, Liu YH, Kim ES. 2002. ${ }^{14} \mathrm{C}$ level at Mt Chiak and Mt Kyeryong in Korea. Radiocarbon 44(2):559-66.

Pearson S, Hua Q, Allen K, Bowman DMJS. 2011. Validating putatively cross-dated Callitris tree-ring chronologies using bomb-pulse radiocarbon analysis. Australian Journal of Botany 59(1):7-17.

Poussart PF, Schrag DP. 2005. Seasonally resolved stable isotope chronologies from northern Thailand deciduous trees. Earth and Planetary Science Letters 235(34):752-65.

Quideau SA, Anderson MA, Graham RC, Chadwick OA, Trumbore SE. 2000. Soil organic matter processes: characterization by C-13 NMR and C-14 measurements. Forest Ecology and Management 138:19-27.

Rabbi SMF, Hua Q, Daniel H, Lockwood PV, Wilson BR, Young IM. 2013. Mean residence time of soil organic carbon in aggregates under contrasting land uses based on radiocarbon measurements. Radiocarbon 55(1):127-39.

Rakowski AZ, Nadeau M-J, Nakamura T, Pazdur A, Paweczyk S, Piotrowska N. 2013. Radiocarbon method in environmental monitoring of $\mathrm{CO}_{2}$ emission. Nuclear Instruments and Methods in Physics Research B 294:503-7.

Randerson JT, Enting IG, Schuur EAG, Caldeira K, Fung IY. 2002. Seasonal and latitudinal variability of troposphere $\Delta^{14} \mathrm{CO}_{2}$ : post bomb contributions from fossil fuels, oceans, the stratosphere, and the terrestrial biosphere. Global Biogeochemical Cycles 16(4):1112, doi:10.1029/2002GB001876.

Reimer PJ, Brown TA, Reimer RW. 2004. Discussion: reporting and calibration of post-bomb ${ }^{14} \mathrm{C}$ data. Radiocarbon 46(3):1299-304

Spalding KL, Bhardwaj RD, Buchholz BA, Druid H, Frisén J. 2005. Retrospective birth dating of cells in humans. Cell 122(1):133-43.

Spalding KL, Arner E, Westermark PO, Bernard S, Buchholz BA, Bergmann O, Blomqvist L, Hoffstedt J, Näslund E, Britton T, Concha H, Hassan M, Rydén M, Jonas Frisén J, Arner P. 2008. Dynamics of fat cell turnover in humans. Nature 453(7196):783-7.

Stuiver M, Polach HA. 1977. Discussion: reporting of
${ }^{14} \mathrm{C}$ data. Radiocarbon 19(3):353-63.

Stuiver M, Reimer PJ, Braziunas TF. 1998. Radiocarbon age calibration for terrestrial and marine samples. $R a$ diocarbon 40(3):1127-51.

Telegadas K. 1971. The seasonal atmospheric distribution and inventories of excess carbon-14 from March 1955 to July 1969. US Atomic Energy Commission Report HASL-243.

Trumbore S. 2009. Radiocarbon and soil carbon dynamics. Annual Review of Earth and Planetary Sciences 37:47-66.

Turnbull JC, Lehman SJ, Miller JB, Sparks RJ, Southon JR, Tans PP. 2007. A new high precision ${ }^{14} \mathrm{CO}_{2}$ time series for North American continental air. Journal of Geophysical Research 112: D11310, doi:10.1029/ 2006JD008184.

Ubelaker DH, Parra RC. 2011. Radiocarbon analysis of dental enamel and bone to evaluate date of birth and death: perspective from the Southern Hemisphere. Forensic Science International 208(1-3):103-7.

Vieira S, Trumbose S, Camargo PB, Selhorst D, Chambers JQ, Higuchi N, Martinelli LA. 2005. Slow growth rates of Amazonian trees: consequences for carbon cycling. Proceedings of the National Academy of Sciences of the USA 102(51):18,502-7.

Vogel JC, Marais M. 1971. Pretoria radiocarbon dates I. Radiocarbon 13(2):378-94.

Wang PX. 2009. Global monsoon in a geological perspective. Chinese Science Bulletin 54(7):1113-36.

Wild E, Golser R, Hille P, Kutschera W, Priller A, Puchegger S, Rom W, Steier P. 1998. First ${ }^{14} \mathrm{C}$ results from archaeological and forensic studies at the Vienna environmental research accelerator. Radiocarbon 40(1):273-81.

Willkomm H, Erlenkeuser H. 1968. University of Kiel radiocarbon measurements III. Radiocarbon 10(2): 328-32.

Worbes M, Junk WJ. 1989. Dating tropical trees by means of ${ }^{14} \mathrm{C}$ from bomb tests. Ecology 70(2):503-7.

Yamada Y, Yasuike K, Komura K. 2005. Temporal variation of carbon-14 concentration in tree-ring cellulose for the recent 50 years. Journal of Nuclear and Radiochemical Sciences 6(2):135-8.

Zimnoch M, Jelen D, Galkowski M, Kuc T, Necki J, Chmura L, Gorczyca Z, Jasek A, Rozanski K. 2012. Partitioning of atmospheric carbon dioxide over Central Europe: insights from combined measurements of $\mathrm{CO}_{2}$ mixing ratios and their carbon isotope composition. Isotopes in Environmental and Health Studies 48(3):421-33.

Zoppi U, Skopec Z, Skopec J, Jones G, Fink D, Hua Q, Jacobsen G, Tuniz C, Williams A. 2004. Forensic applications of ${ }^{14} \mathrm{C}$ bomb-pulse dating. Nuclear Instruments and Methods in Physics Research B 223-224: $770-5$. 